\title{
A Note on Carel Fabritius's Sentry in Schwerin
}

The purpose of this article is to address two questions connected with Fabritius's painting of the so-called Sentry in Schwerin which is signed and dated I654 (fig. I). ${ }^{1}$ The first is related to the provenance of the painting, the second to whether or not the depiction of the city gate is a product of the artist's imagination or whether it includes a reference to a specific topographical situation. In other words: does the relief above the archway showing St Antony Abbot with his pig refer to the Saint as a model of diligence and a kind of moral counterpart to the sentry, as has been suggested ? ${ }^{2} \mathrm{Or}$, is it possible that it is simply used to identify the name of the gate as one of the very few Sint Antoniuspoorten still existing in the United Provinces during Fabritius's lifetime? It should be emphasized that this article does not intend to provide a new interpretation of the Schwerin painting. The following observations are simply meant to add information to the current state of research into what Christopher Brown has called "the most mystifying of all Fabritius's paintings"."

\section{The Provenance of the Painting}

Little is known of the early history of the painting before it was acquired by the dukes of Mecklenburg-Schwerin in the eighteenth century. It has been suggested that the painting could have been identical with "Een stuc schilderij, gedaen door Fabritius, afbeeldende een jager" (A painting done by Fabritius, depicting a hunter) mentioned in a notary's document in Leiden dated December 5 th 1677 , which records the sale of that picture. ${ }^{4}$ However, the Schwcrin painting provides enough evidence to doubt the identification with the one from the Leiden document. Hunting was reserved to noblemen and a couple of privileged and wealthy regents who performed this noble undertaking while spending time at their buitenplaatsen outside the cities. It is wellknown from paintings and documents that these hunters dressed according to their social status and ambitions and therefore hardly like the rather shabby looking man on the Schwerin painting. Furthermore, he is armed with a type of musket which is much too heavy to be used for hunting. Finally, it seems very unlikely that a Dutch notary in 1677 would not have known that a helmet was a very improbable headgear for a hunter.

The unlikely connection between the Schwerin painting and the one described in the 1677 document leaves us with the first mentioning of the picture more than one hundred years later in 1792. In the Schwerin catalogue of that year it is attributed to the monogramist $A$.S. This attribution might have been based, as Gero Seelig has suggested, on a misinterpretation of the similar looking letters on one of the posted notices on the column. 'The attribution clearly indicates that by 1792 the prominent 
Carel Fabritius, The Sentry, signed and dated C. FABRITIUS.I654., vil on canvas, $68 \times 58 \mathrm{~cm}$. Schwcrin,

Staatliches Museum, inv. no. 2477.

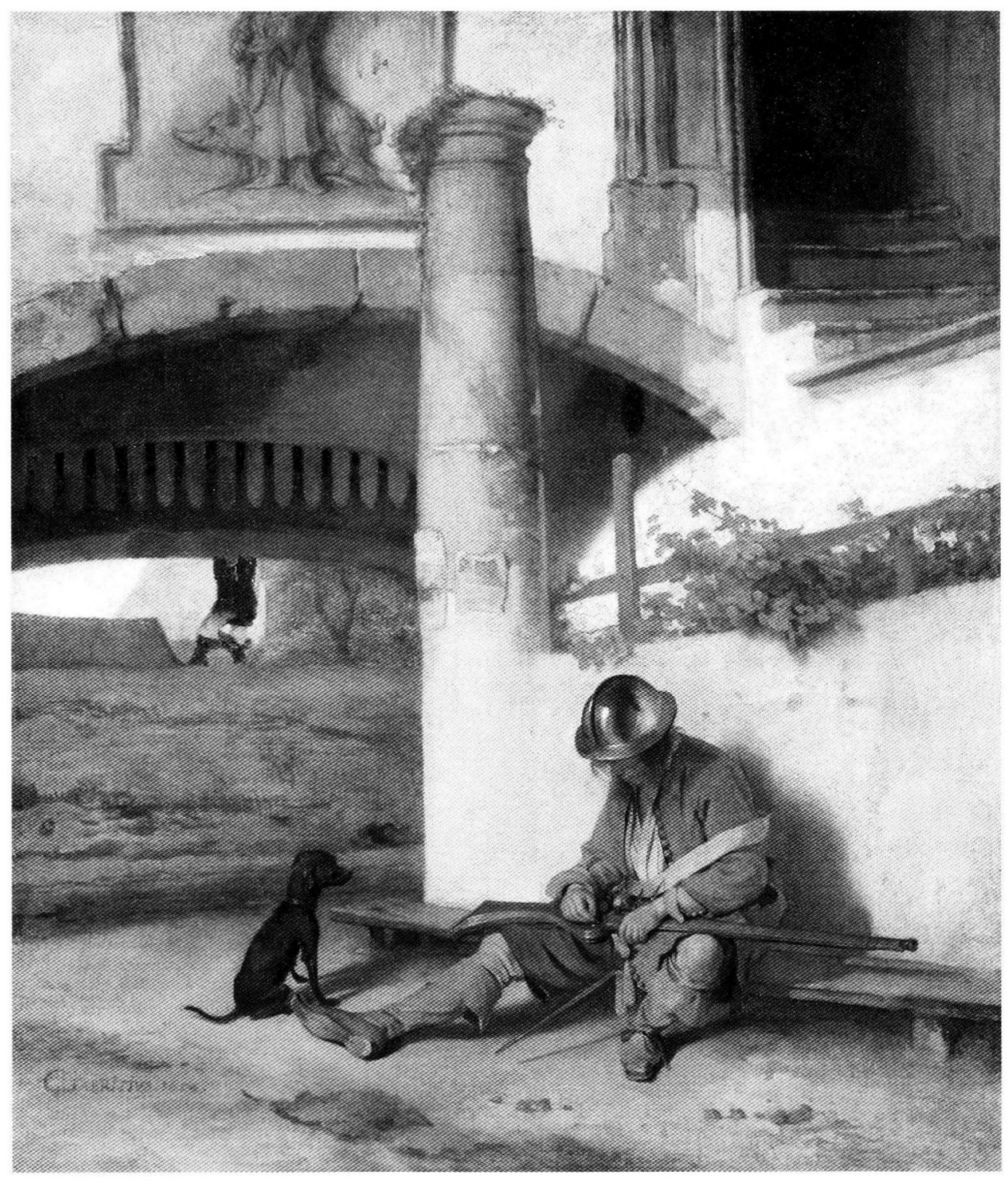

Fabritius signature in the lower left corner of the painting must have been covered. This is confirmed by the French catalogue of 1809 which mentions the original signature as bcing discovered during the recent clcaning of the painting which had been removed from Schwerin by Napoleonic troops, brought to Paris and exhibited there in $1807^{6}$ When exactly before 1792 the Fabritius signature was covered is not known. This however must have happened before the watercolour copy was made which today is part of the Amsterdam Six Collcction (fig. 2). ${ }^{7}$ It shows differences in comparison with the painting. Most important is the omission of the signature, the dog and the sentry's sword. ${ }^{8}$ In 1964 Werner Sumowski was the first to mention the watercolour. He attributed it to the not very well-known Dutch landscape painter Theodoor Wilkens who died in 1748 . $^{9}$ Unfortunately, Sumowski did not communicate the reasons for this attribution. The provenance of the watercolour can be traced back to 1756 when it was part of the Duc de Tallard sale in Paris. In the sale catalogue it is attributed to Van den Eeckhout and described as "A very beautiful coloured drawing, a watercolour which represents a soldier sleeping on a bench at a city gate..." ${ }^{\prime 10}$ This coincides with the fact that the verso of the watercolour shows an inscription: "Gerbrand van den Ecckhout". The lower right corner shows the collectors mark of Cornclis Ploos van Amstel (1726-1798). In 1800 the watercolour was part of the sale of his famous collection. As lot number $2 \mathrm{I}$ in Album D "Containing beauti- 
Here attributed to Hendrik de Winter, The Sentry (after Carel Fabritius), watercolor, $315 \times 277 \mathrm{~mm}$. Amsterdam, Six Colloction.

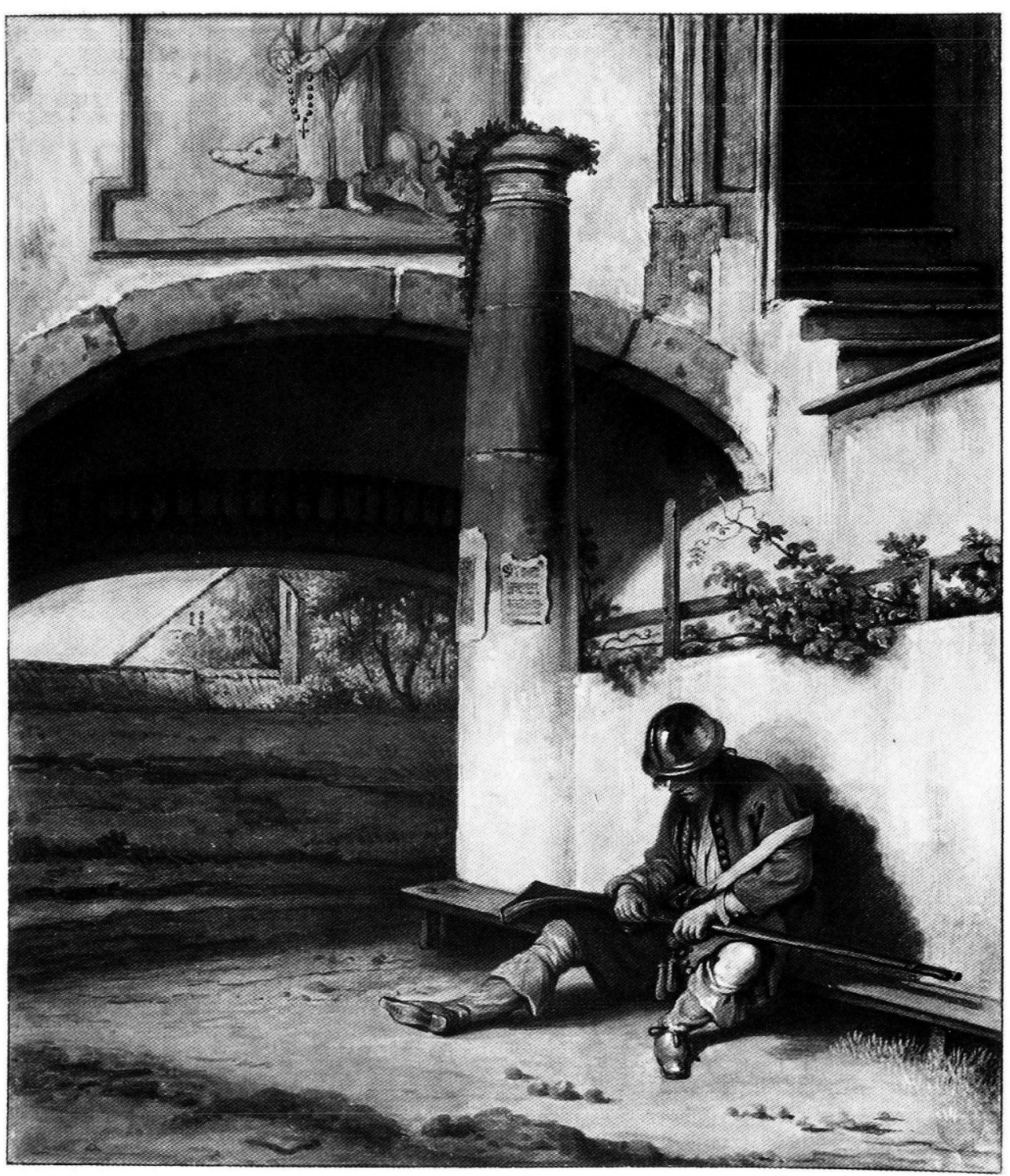

fully coloured drawings by the most famous Dutch masters" we find "A soldier with a gun, sitting in an old building [...] with watercolours, after G. van den Eeckhout, by T. Willckens (sic)". ${ }^{11}$ The same information and attribution was repeated when the watercolour was sold again in Amsterdam in 1819 as part of the collection of Hendrik Willink. ${ }^{12}$

From this provenance we can deduce that already in 1756 it was no longer known that Carel Fabritius was the painter of the Schwerin picture. The date of the Paris sale of the watercolour copy provides a terminus ante for the covering of the signature and the figure in the background which came to light during the recent cleaning of the painting in preparation of the exhibition in The Hague and Schwerin. ${ }^{13}$ Secondly, it is very likely that the attribution of the watercolour to Theodor Wilkens does nor go back any further than to the time around $\mathrm{I} 800$ and to Cornelis Ploos van Amstel who - as is well known - was not always reliable in his attributions.

Let us return to the painting's provenance. The cxact date of its acquisition for the Schwerin collection is unknown. We do know however that the painting is not mentioned there in the 1752 inventory. Therefore, the Sentry must have been acquired between 1752 and 1792 and obviously not as a work by Carel Fabritius. It has gone unnoticed so far that the painting is mentioned in the 1753 sales cataloguc of the collection of Gerhard Michael Jabach (Cologne?-Leghorn 1751). Gerhard Michael, 
3

Sale catalogue G.M. Jabach (Lcghorn), Amsterdam (H. De Leth), 16 October 1753: titlepagc and p. 3 with lot 37. 'The Hague, Rijksbureau voor Kunsthistorische Documentatic. born in Cologne, was the grandson of the famous collector Everhard Jabach (16181695) who settled in Paris in the 1630 s and who in $167 \mathrm{I}$ was forced to sell his huge collection of more than 600 hundred paintings and most of his legendary collection of drawings to Louis XIV. His grandson who settled in Livorno (Leghorn) as a banker inherited parts of the remaining drawing collection. ${ }^{14} \mathrm{He}$ died there on May 26 th 1751 and his collection of around 90 paintings, more than 1000 (mostly Italian) drawings and some curiosities where sold at auction through the art dealer Hendrik de Leth in Amsterdam on 16 October 1753. Most of the drawings were acquired by the Amsterdam collector Antoni Anthonisz. Rutgers (1695-1778). ${ }^{15}$ Jabach's collection of paintings included works by Italian masters such as Parmigianino, Sebastiano Ricci, the Carracci, and Luca Giordano. But he had Flemish and Dutch pictures as well. Remarkable is a group of 11 paintings by Adriaen Brouwer. As one of four paintings attributed to Rembrandt, lot number 37 is described as: Een Soldaat in de Poort zittende en zyn Geweer schoon maakende, van den zelven, h.2v. $3^{\frac{1}{2}} d ., 6.2 v$ (A soldier sitting in a gate cleaning his gun, by the same [i.e. Rembrandt]). ${ }^{16}$ The given measurements convert to $65.6 \times 56.6 \mathrm{~cm}$. The Schwerin painting measures $68 \times 58 \mathrm{~cm}$. The description of the painting as well as the measurements leaves hardly any doubt that the painting must have been identical with the Schwerin Sentry by Carel Fabritius. A similar painting by Rcmbrandt is neither known nor documented.

The annotated copy of the sales catalogue at the Rijksburcau voor Kunsthistorische Documentatie in The Hague mentions that the painting was bought by a certain "Winter" for 32 guilders and to stuivers, the highest price for any of the Rembrandts in the salc (fig. 3). The name is most probably referring to the Amstcrdam draftsman and art dealer Hendrik de Winter (1717-1790) whose family on father's side was related to the German painter Balthasar Denner (I685-1749), also known as "Poren-Denner". During a visit to the buitenplaats Zoetendaal in the province of Utrecht in 1739, Denner portrayed Hendrik de Winter (fig. 4). ${ }^{17}$ From Johan van Gool who in 1751 included De Winter in his Nieuwe Schouburg we know that he was a pupil of Cornelis Pronk (1691-1759). ${ }^{18}$ Until around 1745 De Winter traveled extensively through Holland and the North of Germany where he produced topo-

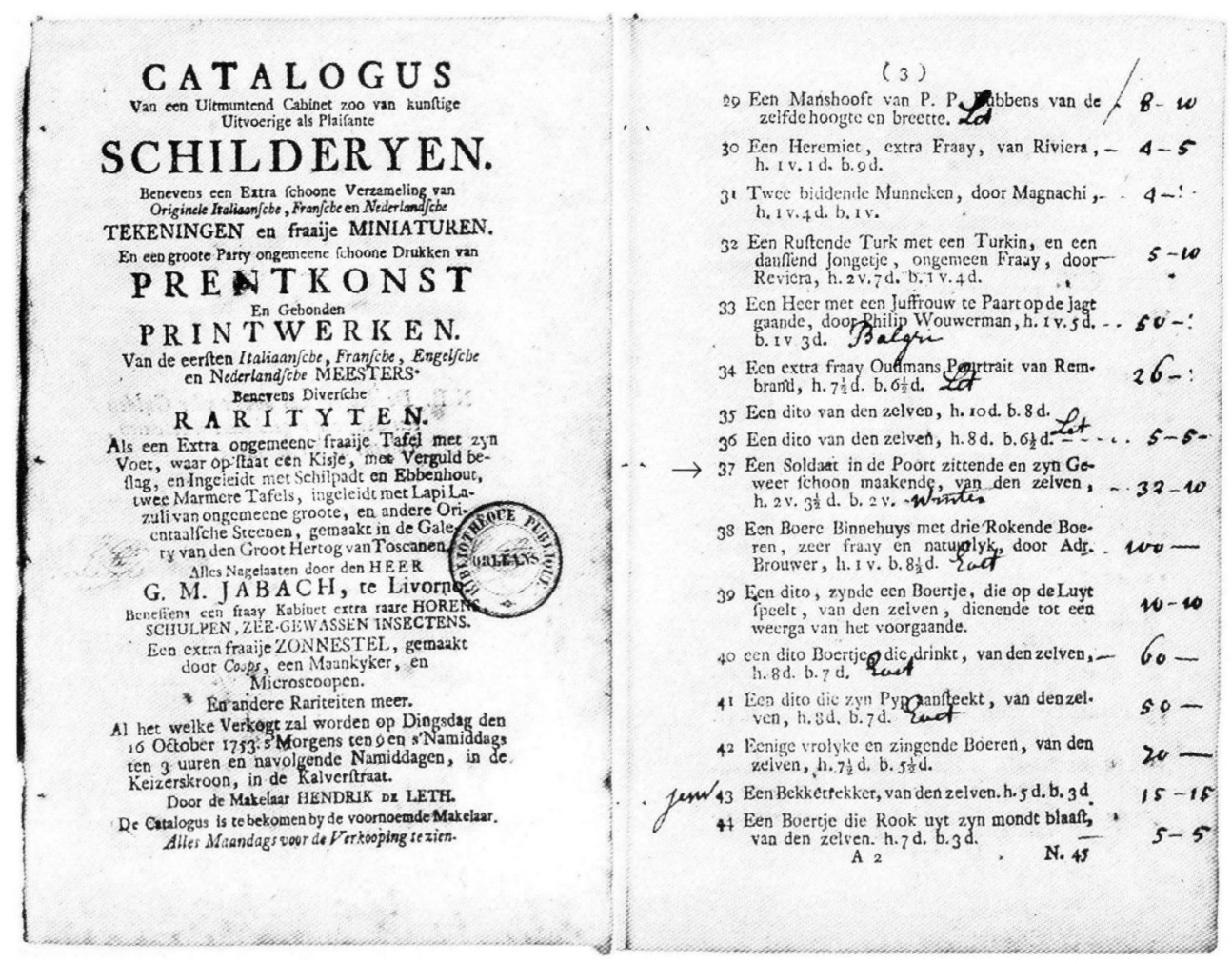


Balthasar Denner, Portrait of Hen drik de Winter, 1739, pencil, red and white watercolours on grey paper. $167 \times 120 \mathrm{~mm}$. Berlin, Kupferstichkabinctt, inv. no. $\mathrm{KdZ}$ 10260. Phoro: Jörg P. Anders.

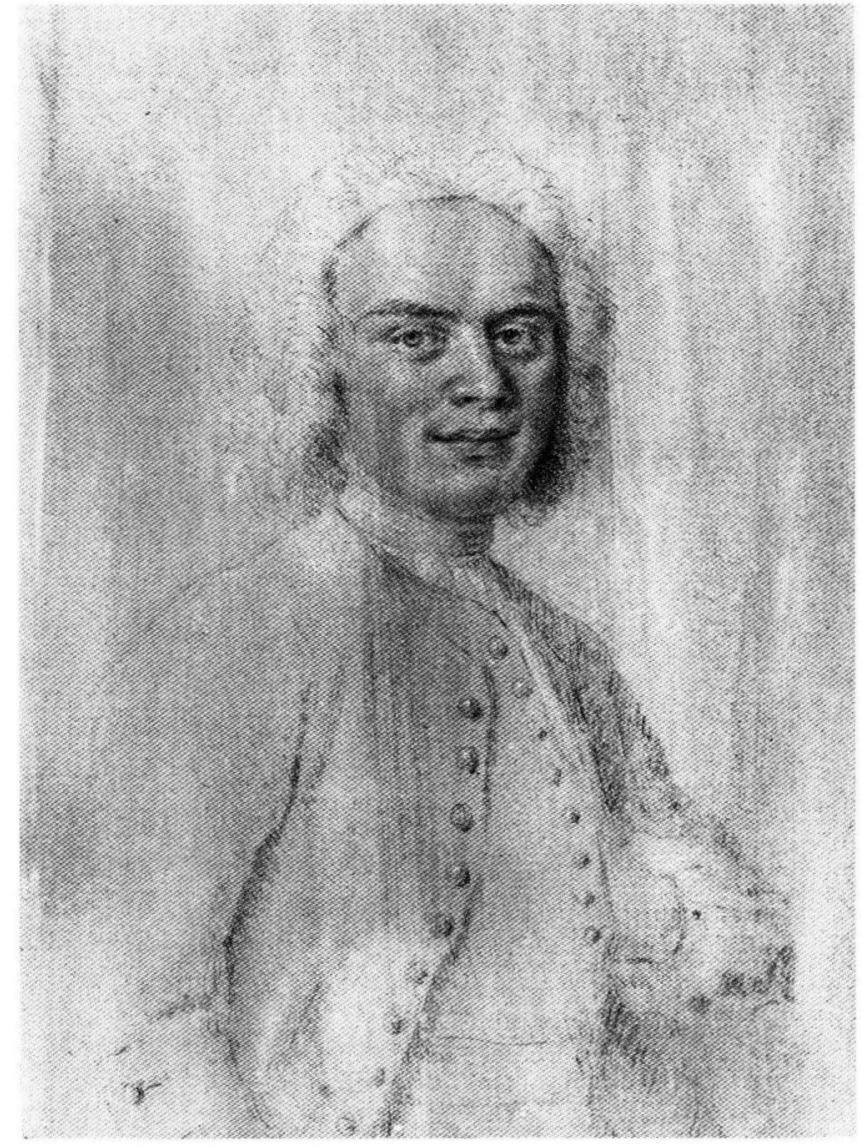

graphical drawings. ${ }^{19}$ From the 1750 s onwards he concentrated more and more on his second career as "kunstmakelaar". He was well-known in the Amsterdam auction rooms, buying and selling prints, drawings and paintings. In 1753 at the Jabach sale De Winter either bought the Fabritius for himself or in commission. Taking this into considcration one wonders how reliable Ploos van Amstel's attribution of the watercolour to Wilkens is. Could it be that it was Hendrik de Winter himsclf who copied the painting he had acquired in 1753 ? We know of at least one other watercolour copy by him after a seventeenth-century painting. In 1758 he copied a painting by Egbert van der Poel (1621-1664) depicting Delft after the explosion of the powder magazine in $1654 .{ }^{20} \mathrm{Did} \mathrm{De}$ Winter produce these watercolours after seventeenthcentury paintings to send them to potential buyers of these paintings? This might cxplain why the drawing of the Sentry turned up in the Duc de Tallard sale in Paris in 1756 .

When exactly after 1753 and whether Hendrik de Winter sold the painting directly to the duke of Mecklenburg-Schwerin can only be answered with the help of the Schwerin archives. So far, no information regarding the date of acquisition has turned up. Duke Christian Ludwig of Mecklenburg-Schwcrin (1683-1756) and his son Friedrich (1717-1785) both visited the Low Countries and were both keen collectors of Dutch paintings. ${ }^{21}$ Because the painting was auctioned in Amsterdam only three years before the death of Duke Christian Ludwig, it is more likely that it was his son Fricdrich who acquired it.

Nothing is known about the painting's provenance before it was sold in Amsterdam in 1753 as part of Gerhard Michael Jabach's collection. In any case the painting did not come with the works of art Gerhard Michael inherited from his grandfather or, to be more precise, the painting is not mentioned in Everhard Jabachs inventory of ${ }_{1696 .}{ }^{22}$ That the painting was sold as a Rembrandt in 1753 is less surprising considering the absencc of reliable information about Fabritius's life and the lack of knowledge 
about his style during the eighteenth and early nineteenth centuries. ${ }^{23}$ Around 1750 a painting attributed to Rembrandt would obviously fetch a higher price than a signed work by Carel Fabritius.

\section{The Location of the City Gate}

It has often been pointed out that the architectural setting of the Schwerin picture contains a number of strange elements. Most uncommon is the column in front of the gateway with a raised portcullis. The column marks the end of the diagonally running wall behind the sentry. It has no obvious function and cven obstructs the full use of the opening of the gateway. Furthermore, its position in relation to the space between the two arches of the gateway and the length of the sunlit wall is not rendered convincingly. Another strange feature of the setting is the situation outside the gateway. In 1882 Friedrich Schlie described it as a "shallow vaulted archway with a view of an open field, a long flat tiled roof and a higher building surrounded by trees.". However, a closer look reveals that there is a wall and a narrow path just outside the archway. This wall which obscures most of the view, does not consist of stone- but of earthwork. Behind this wall one sees a tree and a reddish rooftop. The triangular beige form between the roof and the tree can be identified as part of a second house. In order to function properly as part of a city's security precautions most city gates were built in such a way that approaching individuals and groups could be seen from far away. ${ }^{25}$ An obstructed view like in Fabritius's painting would leave the sentry or the members of the civic guards no time to react to unexpected intruders. This as well as the unlikely position of the column and its combination with a gatcway seems to confirm that Fabritius based the architecture on invention rather than on observation. But can we be really sure about this? Is it possible that Fabritius has combined invented with observed elements or even with architectural structures painted from memory?

Above the inner arch of the gate Fabritius has prominently included a relicf depicting Saint Antony Abbot with his attribute, a pig. Apparently the artist considered it important to identify the gateway as a Sint Antoniespoort. Saint Antony-confraternities and city gates named after this popular saint whose help protected against the

Jan van Kcsscl, The Sint Antoniespoort in Amsterdam, 1664 , black chalk, brush in grey, $194 \times 303 \mathrm{~mm}$ Amsterdam, Gemcentearchief, Collection Van Eeghen.

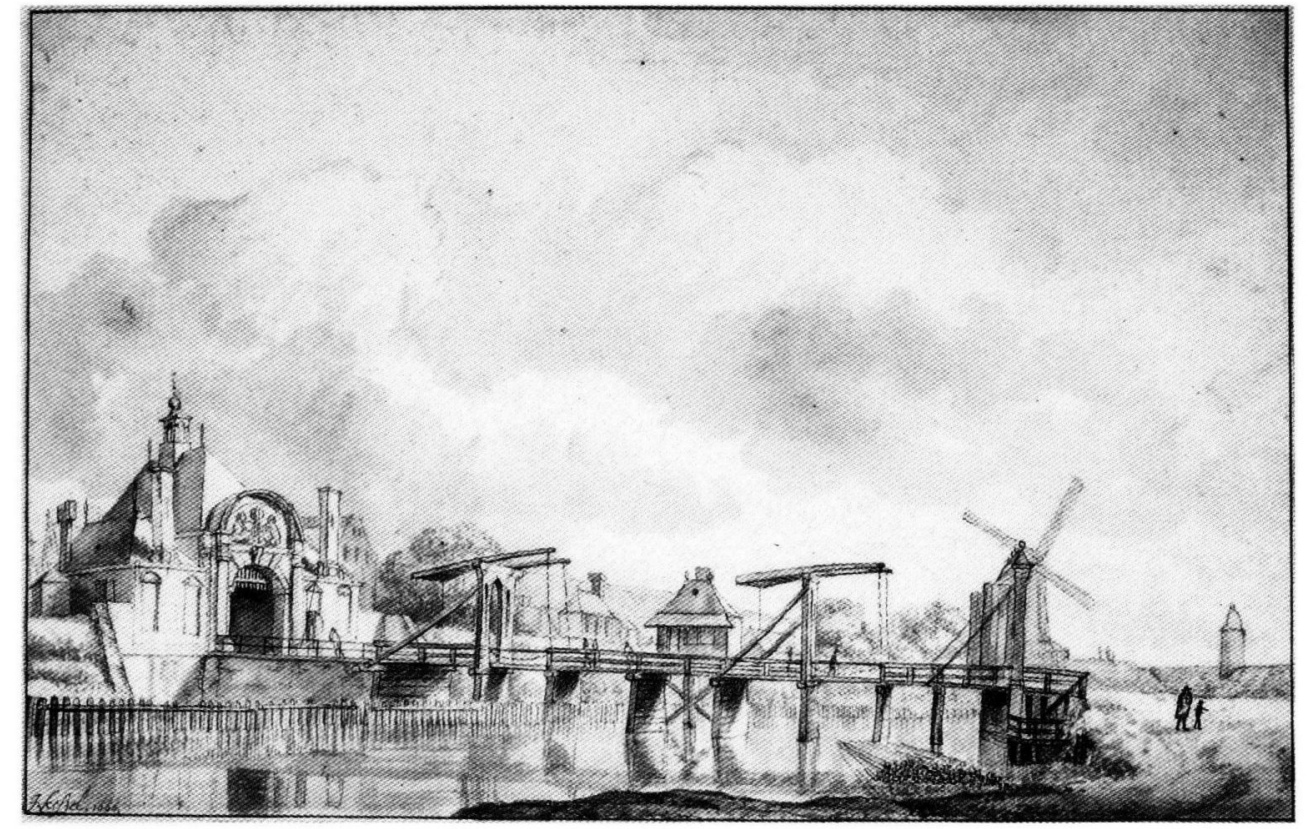


6

The Sint Anthonispoort in Nijmegen from the south (2004). Photo: author.
'Ihe Sint Anthonispoort in Nijmegen from the north (2004). Photo: author.

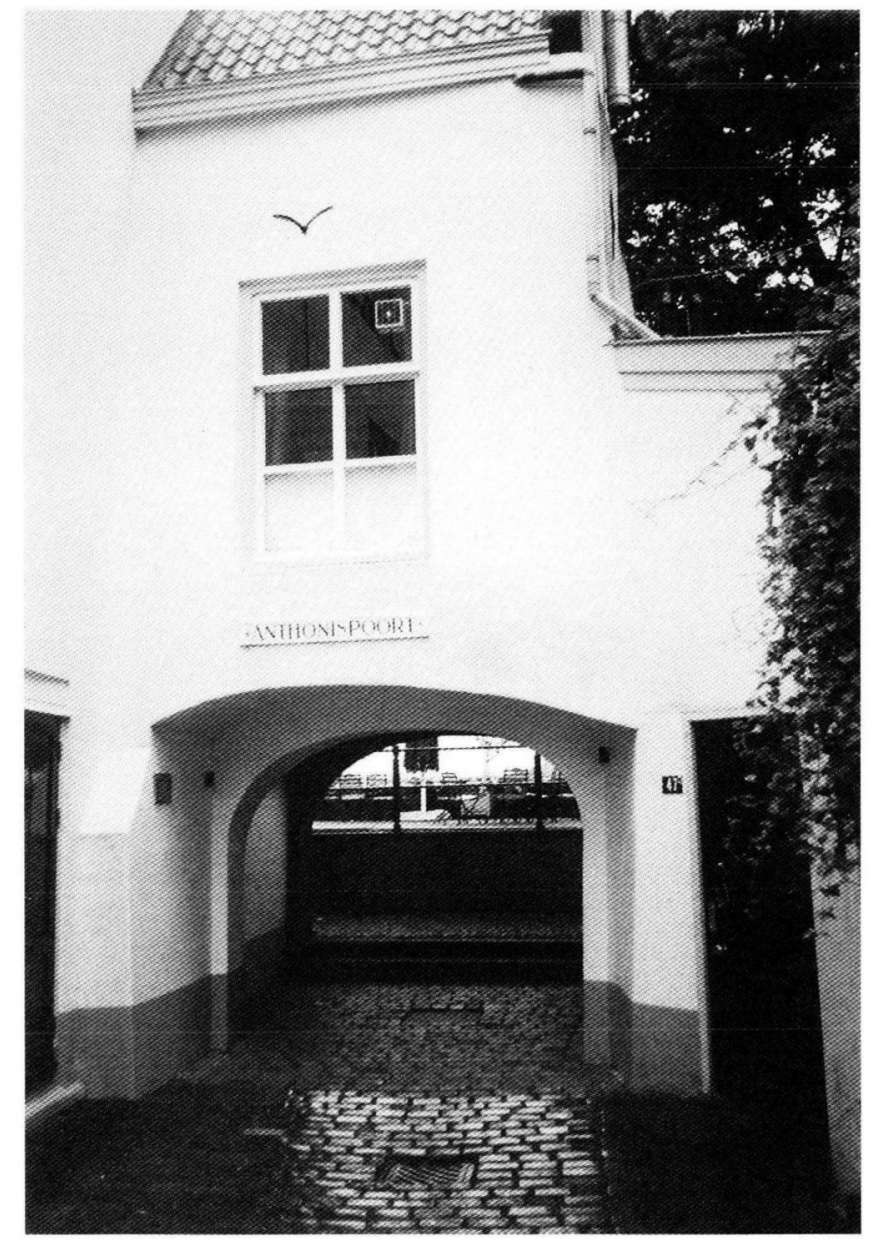

plague were no exceptions especially in the Lower Rhine area. In the United Provinces however, we know of no more than three city gates of that name. The one in 's-Hertogenbosch was destroyed in 1624 already. Another one was located in Amsterdam. In 1593 it was built at the end of the Breestraar (exactly where the Mr. Visserplein is today) replacing the old Sint Antoniespoort (today the Waag) on the Nieuwmarkt. It was close to Rembrandt's housc where Carel Fabritius studicd in the early 1640 s. Jan van Kessel's drawing from 1664 shows the Amsterdam Sint Antoniespoort before it was demolished in 1670 (fig. 5). ${ }^{26}$ The situation of the city gate which was partly built of brick and partly of sandstone and which showed pediments with the coat of arms of Amsterdam on both sides is very different from the situation in the Schwerin picture. Similarities between the two are restricted to their name.

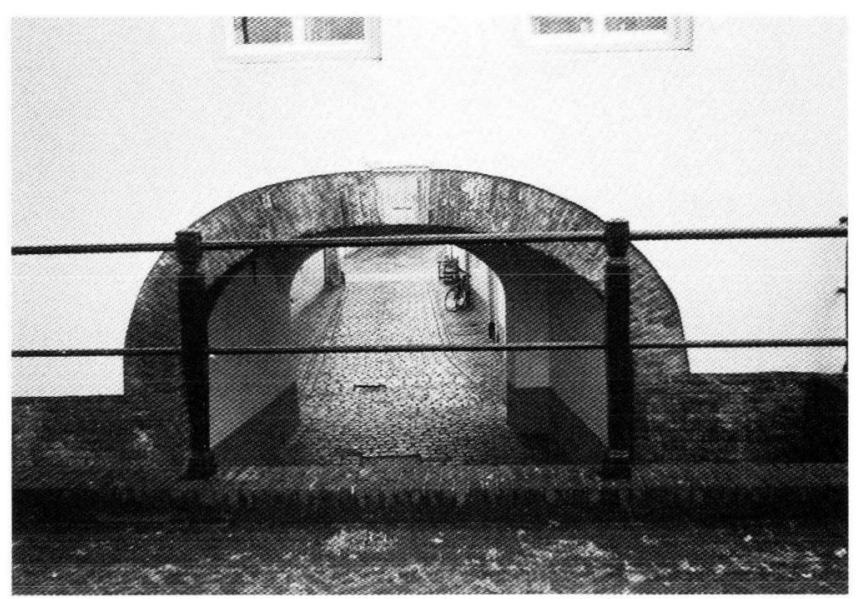


Rudolphus Lauwerier, The Waalkade in Nijmegen, 1878 , watercolour, $173 \times 227 \mathrm{~mm}$. Nijmegen, Museum Het Valkhof.
The third Sint Antonicspoort can be found in the city of Nijmegen. ${ }^{27}$ The gate has a certain fame in the city's history because it was here that in 1589 Maarten Schenk (1549-1589) tried in vain to force his way into Nijmegen with his troops to free the occupied city (since 1585 ) from the Spaniards. The modest gate is facing the river Waal and is located at the end of a narrowing path connecting the Lage Markt with the Waalkade (fig. 6). ${ }^{28}$ It is medieval by origin but was radically changed in $1609-1610$. The last restoration took place in 1987 and today it consists of a rectangular twostoried gate house with a saddle roof. The gateway is covering most of the lower storey. It is flanked by two houses which are also late medieval by origin with changes and additions dating from the sixteenth and scventeenth centuries. Despite the recent restoration of the gateway and the adjacent houses the basic structure is fairly well preserved. There is, however, no indication whatsoever that the city gatc in Nijmegen originally featured a column like the one in the painting. If this is the city gate the artist depicted we have to conclude that this element is very likely a product of the artist's imagination. However, in addition to more general similarities it is also the very specific situation outside the gateway that strongly rescmbles the one painted by Fabritius. Like in the Schwerin painting in Nijmegen a wall raises immediately behind the gateway's field side leaving just enough space for a little path running parallel with this wall (fig. 7). This situation is not the result of a recent restoration but goes back to the seventeenth century. In order to protect the city from flooding the embankment of the river Waal was raised in 1638 . The newly created elevated space between the river and the first row of houses including the Sint Antoniespoort was used to plant trees and built some houses. A watercolour from 1878 by Rudolphus Lauwerier (1797-1883) indicates that even at the end of the nineteenth century the Waalkade featured trees and some buildings (fig. 8). ${ }^{29}$ This unique situation comes close to what Carel Fabritius painted in his Schwerin picture. The recent cleaning of the painting has even revealed that originally he had planned to include a man walking on the wall behind the gateway. There is still no convincing interpretation of this figure. The depiction of the figure walking on the wall immediately behind the city gate does, however, confirm that Fabritius had rather some kind of elevation in mind which was suitable for strollers. What the Sint Antoniespoort in Nijmegen and

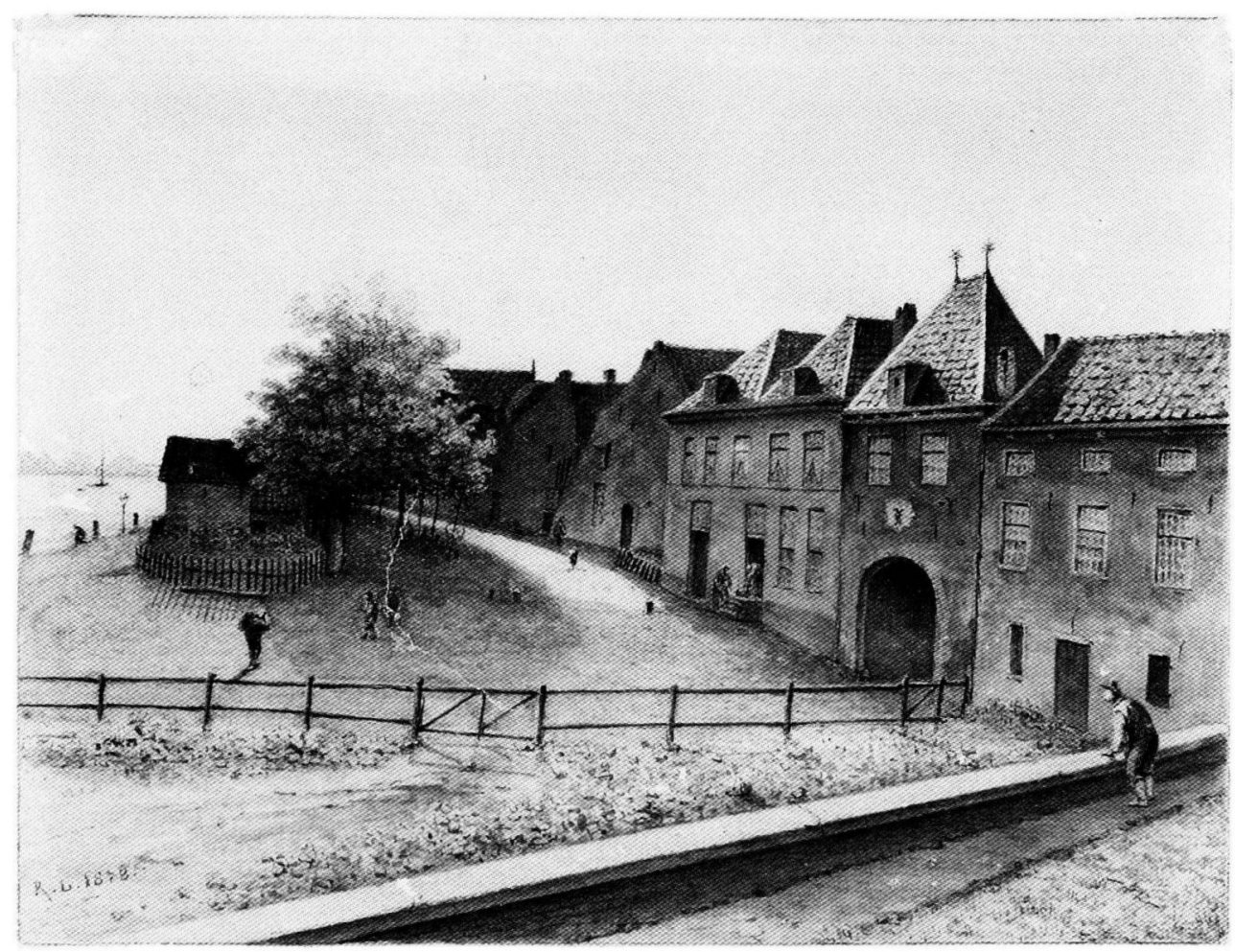


Johannes Blacu, Toonneel der steden van de Vereenighde Nederlanden (Stedenbock), 1649: Bird's-eye view of Nijmegen (detail)

IO $\triangle D$

Hendrik Feltman, Bird's-eye-view of Nijmegen (dctail), 1669 , canvas, 251 $x 28 \mathrm{I} \mathrm{cm}$. Nijmegen, Museum Het

Valkhof. The location of the gateway is indicated by the arrow.
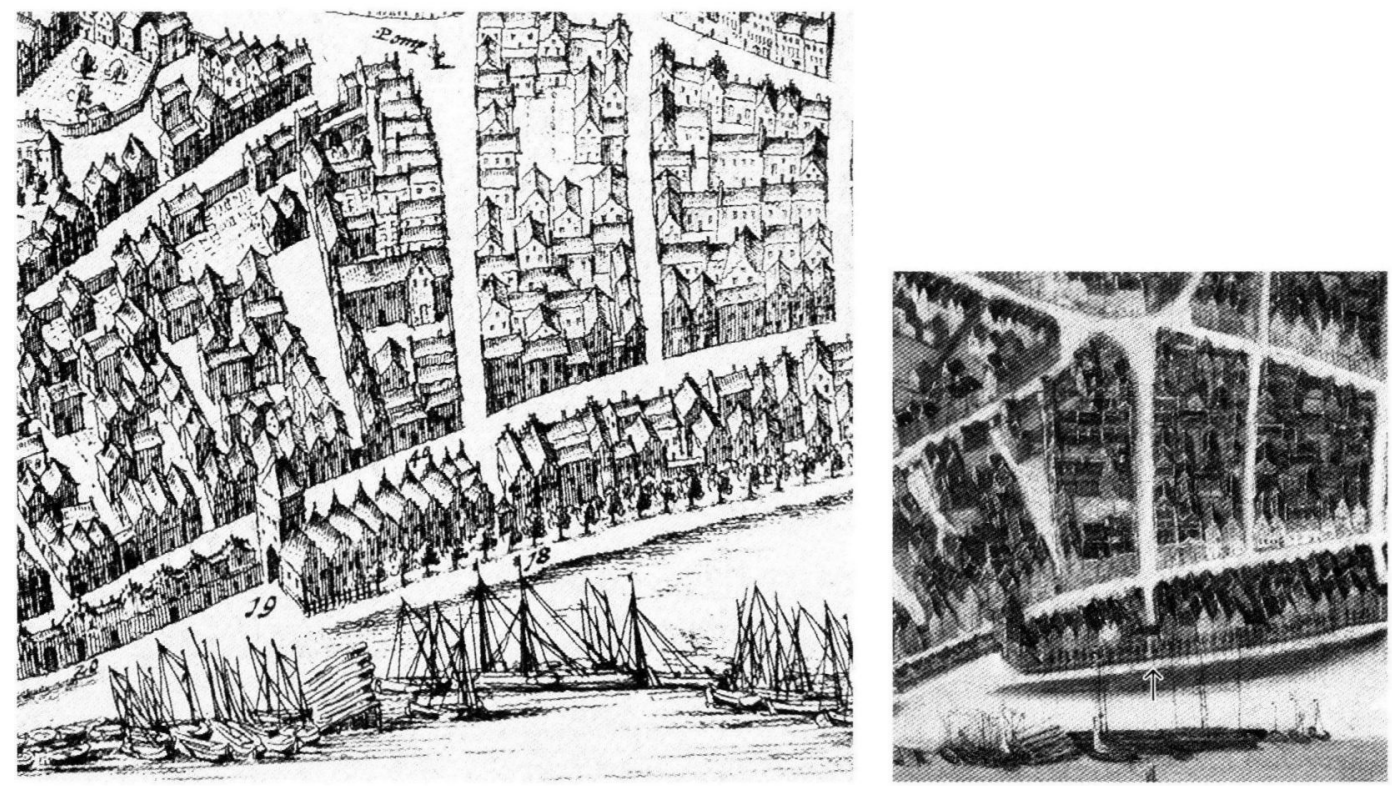

the one Fabritius painted share is their specific and unique deviation from other city gates in the United Provinces.

However, the Sint Antoniespoort in Nijmegen could hardly have served as the direct model for Fabritius. The reasons for this are related first of all to the history of the city gate. We know that after the rising of the embankment in 1638 the gateway was closed and bricked up. It was only in 1987 that it fully re-surfaced. Unfortunately, we do not know exactly when the gateway disappeared underneath the ground. It must have happened around the middle of the seventcenth century. ${ }^{30}$ On the bird's-eyc view of Nijmegen published in Blaeu's Stedenboek of 1649 and designed by Hendrik Feltman who received the commission in 1647, the Sint Antoniespoort is still visible and even mentioned as $S$. Theunis poortjen under number 18 in the legend of the map (fig. 9). In the painted bird's-eye view which Feltman produced in 1668-1669, however, the gateway is obscured by trees (fig.IO). ${ }^{31}$

Whether or not the gate was visible in 1654 when Fabritius painted the Schwerin Sentry is hard to say and cannot be proven with certainty. It is also questionable whether the protestant city council of Nijmegen would have allowed a relief of a saint in such a prominent place. Furthermore it is known that the gate in Nijmegen had two sets of doors of which the original hinges can still be seen (compare fig. 6). Finally, there is no indication that the gate had a portcullis during the seventeenth century. Thesc clcments differ from what Fabritius depicted in his Schwerin painting. What the two Sint Antoniespoorten do share, however, is their specific and unique deviation from the other city gates in the United Provinces. This seems more than just coincidence. So far therc are no documents confirming a connection between Carel Fabritius and the city of Nijmegen. However, we do know of many other seventeenth-century painters who visited Nijmegen. It was the city's favorable geographical situation between the rivers Maas and Waal which attracted travelers from the provinces in the west. Not only landscape painters were fascinated by the impressive medieval architectural ensemble known as the Valkhofburcht which dominated the city until its demolition in 1795-97. Jan van Goyen (1596-1656), Anthonie Waterloo (ca. I610-1690) and Lambert Doomcr (1624-1700) visited the city more than once, and many others artists traveled through $\mathrm{Nijmegen.} \mathrm{It} \mathrm{cannot} \mathrm{be} \mathrm{ruled} \mathrm{out} \mathrm{that} \mathrm{Carel}$ Fabritius was one of them. So far there is no documentary evidence to prove a relation between Fabritius and the city of Nijmegen. However, further research into the artist's family background preceding the time in Middenbeemster and the origin of his patrons might be able to establish a connection between the artist and the city. 
${ }^{1}$ I am grateful to G. Lemmens and J. van der Hoeve for discussing the history of the Sint Antoniespoort in Nijmegen with me. Special thanks to R. I. te Rijdt who shared his knowledge of cighteenth-century Dutch drawings and to $M$. de Winkcl who drew my attention to the Jabach salc.

For the painting in Schwerin see Chr. Brown, Carel Fabritius. Complete Edition with a "catalogue ratsonne", Oxford 1981, pp. 48, 127-128, no. 8 with col. plate IV and plates 8 , 27 (with carlicr literature); L. Jürss (ed.), Holländische und flämische Malerei des 17. Jabrhunderts. Bestandskatalog I, Staatliches Museum Schwerin, Schwcrin 1982, pp. 9, 99, nr. 90 with ill., and W. Sumowski, Gernälde der Rembrandt-Schüler, 6 vols., Landau/Pfalz 1983-1994, vol. 2, p. 986, no. 607, p. 994 (col. ill). See also W. Licdtke, A View of Delft: Vermeer and his contemporaries, Zwollc 2000 , pp. $36-37$ with fig. 34 and plate VI; W. L.iedtke et al., exh. cat. Vermeer and the Delft School, New York (Mctropolitan Muscum of Arr)/London (National Gallery) 200I, pp. 257-260, cat.no. 20 (entry by $A$. Rüger) with col. ill., and, most recently, F. J. Duparc, G. Seelig, A. van Suchtelen, exh. cat. Carel Fabritius 1622-I654, The Hague (Koninklijk Kabinct van Schilderijen Mauritshuis)/ Schwerin (Staatliches Museum) 2004-2005, pp. I41-146, no. I2 (entry by $\mathrm{G}$. Seclig) with col. ill.

${ }^{2}$ Liedtke 2000 (note I), p. 37.

${ }^{3}$ Brown I981 (note 1), p. 48 .

4 This has been suggested by Brown 198I (note I), p. 128 and p. 157 , documents nos. 44 and 45 . Interestingly, it was T. Thoré (18071869) who referred to the painting as the Chasseur en repos (Hunter at Rest). However, he knew it only from an engraving and was not awarc of the Leiden document. For the Thoré reference see New York/ London 200 I (note 1), p. 257.

'See The Hague/Schwerin 20042005 (note I), p. 141.

'For the painting's history between 1807 and 1815 see The Hague/ Schwerin 2004-2005 (note I), p. 14I and P. 146 , note 3 .

'Reproduced in The Hague/ Schwerin 2004-2005 (note r), p. 144, fig. 12c, as by 'Theodor Wilkens?
${ }^{8}$ An cxamination of the watercolour carried out by Jorgen Wadum on the occasion of the Fabritiusexhibition in The Hague revcaled that originally the dog was copied as well. The animal must have been covered later but the outlines are still visible (verbal communication).

${ }^{9}$ W. Sumowski, 'Zum Werk von Barend und Carel Fabritius', Jahrbuch der Statatlichen Kunst. sammlungen in Baden-Wirttemberg 1 (1964), pp. 188-198, esp. p. 198, note 47 (a "lcicht variierte Aquarelkopie des Schweriner Gemäldes befindet sich B. Fabritius zugeschrieben, in der Six-Stifung"). After the death of Thcodoor Wilkens in 1748 his estate was sold on June $17^{\text {th }}$ of that year in Amsterdam [F. Lugt, Répertoire des catalogues de ventes publiques intéressant l'art ou la curiosité ..., 8 vols., The Hague 1938, no. 687]. Neither the painting by Fabritius nor the watercolour is mentioned in the sales catalogue.

${ }^{10}$ Sale Duc de Tallard, Paris (Remyct ct Glomy: C.P.: Grimard), 22 March - 13 May 1756 [Lugt 1938 (note 9), no. 910], lot 410: 'Van Eckoutte, Eleve de Rembrandt. Un très beaux Dessein colorié à gouazze, représentant un Soldat factionnairc endormi sur un banc, à la porte d'une Ville. Il est d'un trés beau fini, \& d'une effet admirable.' See also Ch. Blanc, Le Trésor de La Curiosité tiré les catalogues de vente, vol. I, Paris 1857, p. 83: 'Van Eeckhout. Un soldat endormi sur un banc. A la gouache. ro 8 liv.

${ }^{11}$ Salc C. Ploos van Amstel, Amsterdam (Ph. v.d. Schlcy, J. de Bosch et al.), 3 March (and following days) 1800 [Lugt 1938 (note 9), no. $603 \mathrm{I}$ ], Kunstboek D: 'Inhoudende fraai gecouleurde Teekeningen, door de beroemdste Nederlandsche Mccsters.' No 21: 'In een anticq Gebouw, zit een Krygsman met cen Snaphaan: fraai van licht en bruin, met Dekverven, naar $G$, van den Eekhour, door T. Willekens (sic)' (for 43.- Guilders to Andriessen); see also "Index op de tekeningen in de veiling C. Ploos van Amstel, 3. III. 1800 e.v.d.', in: 'Th. Laurentius, J.W. Niemeijer, Jhr G. Ploos van Amstel, Cornelis Ploos van Amstel 1726-1798. Kunstveraamelaar en prentuitgever, Assen I980, pp. 337 379, especially p. 366 (s.v. Wilkens, T.).
${ }^{12}$ Sale Hendrik Willink, Amsterdam (Roos, de Vries, Brondgeest), 6 Deccmber 1819 [Lugt 1938 (note 9), no. 9691], Kunstboek E: 'Waarin moderne gekleurde Tckeningen, door Nederlandsche Meesters.' No 15: 'Een rustend Militair bij een Gebouw; met watcrverven, door $\mathrm{T}$. Wilkens, naar G. van den Eckhour' (for 51.- Guilders to de Vries).

${ }^{13}$ The results of the clcaning of the painting which was carried out by R. Kränz (Hamburg) were presented to the public on the occasion of a conference organized by the Staatliches Muscum Schwerin on May 28th 2005 (R. Kränz, Zur Restauricrung des Gemaildes Dic Torwache).

${ }^{14}$ On Gerhard Michael Jabach and his collection of drawings see $F$. Lugr, Les Marques de Collections de Dessins ér d'Estampes, Amsterdam 1921, here reprint The Hague 1956, p. 552; see more recently B. Py, Everbard Jabach Collectionneur (I618I6os). Les dessins de linventaire de 1695 , Paris 2001, esp. Pp. 19-20, and M.C. Plomp, Hartstochtelijk Verzameld. I 8 de-eenwse Hollandse verzamelaars van tekeningen en bun collecties, Paris/Bussum 2001, p. 49.

${ }^{15}$ For this sec the introduction by Comelis Ploos van Amstel to the caralogue of Rurgers' sale in 177 8. Salc Antonie Anthz. Rutgers, Amsterdam (van der Schley, C. Ploos van Amstel [...], J. Yver), I December 1778 [Lugt 1938 (notc 9), no. 2920]. For Rutgers' and his collection see Plomp 200 I (note 14), passim.

${ }^{16}$ Sale G.M. Jabach (Livorno), Amsterdam (H. de Leth), 16 October (and following days) 1753 [Lugt 1938 (note 9), no. 816], lot 37 (for 32.10 Guilders to Winter).

${ }^{17}$ For the drawing see E. Bock, Zichnungen Deutscher Meister im Kupferstichkabinett zu Berlin, Berlin 1921, p. 149, no. 10269, and L. Kooijmans, E.A. de Jong, H.M. Brokken (red.), cxh. cat. Pronk met Pen en Penseel. Cornelis Pronk (1691-1759) tekent Noord-Holland, Haarlem (De Vleeshal) 1997, pp. 163, 169, note 51 (the drawing is inscribed: 'Hendrick Winter in Amsterdam Balthasar Denner fecit auf Zoetendaal in der Provinz Uytregt Ao 1739').

${ }^{18}$ J. van Gool, De Nieuwe Schouburg der Nederlantsche Kunstschilders en Schilderessen, vol. 2, The Hague 1751, pp. 369-370. 
${ }^{19}$ For Hendrik de Winter's biography and his work as a topographical draftsman see B. Gerlagh, L. Kasteleyn and J. Otten, 'Leerlingen van Pronk', in: Haarlem 1997 (note i7), pp. IsI-I69, csp. pp. 163-I66.

${ }^{20}$ Amsterdam, Rijksprentenkabinet, Rijksmuseum (inv. no. FM 2106) The warercolour is inscribed by De Winter: 'Het springe van het Kruytmaggeseyn tot Delf den I2 Octob. 1654. H. de Winter, 1758 naar Egbert van der Pocl, I654".

${ }^{21}$ For this comparc E. Korthals Altes, "The art tour of Friedrich of Mecklenburg-Schwerin', Simiolus 31 (2004-2005), pp. 216-250.

${ }^{22}$ See Vicomte de Grouchy, 'Fuverhard Jabach. Collectionneur Parisien', Mémoires de la Sociéte de l'Histoire de Paris et de l'lle de France XXI, 1894, pp. 217-292. A thorough study of the Dutch merchants in Leghorn and their intensive collections of paintings and drawings is still a desideratum.

${ }^{23}$ F.J. Duparc has rightly emphasized the fact that - as far as we know - only two other paintings now recognized as being by Fabritius were recorded on the art market during the eighteenth century: the Warzaw Raising of Lazarus as a work by Rembrandt and the
Salzbury Hagar and the Angel as by Ferdinand Bol. See for this The Hague/Schwerin 2004-2005 (note I), pp. 68-72.

${ }^{24} \mathrm{~F}$. Schlic, Beschreibendes Verzeichnis der Werke älterer Meister in der Grossherzoglichen Gemälde-Gallerie $z u$ Schwerin, Schwcrin 1882, p. ${ }_{177}$ ("Alach gewölbter Durchgang, welcher einen Blick auf cin freies Feld zulässt, wo in der Ferne ein langes niedriges Zicgcldach und cin höheres von Bäumen umgebenes Haus sichtbar sind").

${ }^{25}$ For the history and development of city gates in the Northern Netherlands see H. Janse, Th. Van Straalen, Middeleeuwse Stadswallen en Stadspoorten in de lage landen, Zaltbommel 1974 .

${ }^{26}$ For the drawing sec B. Bakker, E. Fleurbaay, A.W. Gerlagh (eds.), De verzameling Van Eeghen. Amsterdamse tekeningen 1600-1950, Zwolle 1989, pp. 102-103, no. 41 with ill.

${ }^{27}$ During the first time of its existence the Sint Antonicpoort in Nijmegen was also called Mulicumspoortje.

${ }^{28}$ For this see F. Gorissen, StedeAtlas van Nijmegen, Brugge 1956 p. I5I, no. 68; J. Brinkhoff, $\mathrm{G}$. Lemmens, De Stadspoorten. His- torisch Nijmegen in pen en penseel, Nijmegen 1966, pp. 29-30, 92; J.J. Verbeek, F.J. Hermans, 'Omwalling en stadspoorten', in: Het stadhuis van Nijmegen, Nijmegen 1982, pp. 100-IOS, and most recently J. van der Hoeve, 'Huizen als stadsmuur tussen Lage Markt en Waalkade', in: H. Peterse et al (eds.), Verborgen verleden. Bouwhistorie in Nijmegen, Utrecht 2004, Pp. 91-105, esp. pp. 94-98.

${ }^{29}$ For the artist and the watercolour see Brinkhoff/Lemmens 1966 (note 28), pp. 80,95 .

${ }^{30}$ Rescarch into the city archive of Nijmegen has shown that the datc of when exactly the gateway was walled up cannot be cstablished. Payments to gate-keepers are mentioned during the scventcenth century. Unfortunately, not in al! cases the names of the city gates arc specified. I am grateful to C.C. van der Woude from the Municipal Archive in Nijmegen who checked some of the city's account books regarding payments to gatc-keepers in Nijmegen around the middle of the seventeenth century (written communication 13 May 2003).

${ }^{31}$ Sec G. Lemmens, Nijmegen in 1660: Vogelvluchtgezicht van Hendrik Feltman, Nijmegen 2003. 